\title{
Salutogenesis and the Sense of Coherence in Middle Adulthood
}

\author{
Ottomar Bahrs, Felix Deymann, and Karl-Heinz Henze
}

\section{Introduction}

The life course can be understood as a dynamic learning process that is socially pre-structured in the sense of electoral opportunities but is experienced and lived individually (Erikson, 1980). This is how life phases with expected developmental tasks and corresponding risk-resource profiles can be described - culturally differently structured. Besides, critical - usually unexpected - life events must be taken into account, which in turn present specific challenges and require flexible coping strategies. The formation of personal and social identity (Goffman, 1975) is thus a continuous challenge of 'making yourself who you are' (Sartre, 1964, p. 1977-1979, translated by the authors) and which is also expressed in the formation of the SOC (Antonovsky, 1987; Ventegodt et al., 2003).

For a long time, the late middle age has been considered an undramatic phase of life, but it is increasingly beginning to acquire its particular profile (Perrig-Chiello \& Perren, 2005; Perrig-Chiello et al., 2008). We focus here on a phase typically observable in the sixth decade of life, which can be described as the initiation of the transition to devocationalization and a change in family responsibilities. It is thus an approach towards balancing and future orientation, looking for a coherent life.

Crises, whatever their causes, as well as long-standing problems, can lead to a need for help from health professionals who can provide support in defining individual health objectives and in developing ways to achieve them according

O. Bahrs $(\bowtie)$

University of Düsseldorf, Düsseldorf, Germany

Umbrella Organization Salutogenesis, Göttingen, Germany

e-mail: obahrs@dachverband-salutogenese.de

F. Deymann

University of Göttingen, Göttingen, Germany

K.-H. Henze

Lou Andreas-Salomé Institut for Psychoanalysis and

Psychotherapy, Göttingen, Germany to the situation, the person and the problem. The often implicit personal life goals must be taken into account.

This chapter uses a case study to illustrate how general practitioners can contribute by using a specific framework for encounters (review dialogue) to the naming, modification, design and development of health goals. Further, we want to illustrate how this kind of encounter can promote the use and formation of salutogenic resources, and how this relates to the life situation and life history of persons in chronic conditions. We focus on the challenges of the sixth decade of life - here, especially the care and support of parents as the continuing effect of developmental tasks. From this perspective, for example, the tasks of developing autonomy and detaching oneself from the parental home, which is typically on the agenda in earlier phases of life, become relevant again in a modified form. The meaning of the tasks at hand is shown employing a biographical reconstruction and gives an idea of the interweaving of coexisting constellations in the family context (cf. Oevermann, 2000). This chapter underlines, based on the specific transitional situation in the sixth decade of life, that life tasks need to be emphasized and taken into account for the joint negotiation of health goals.

We illustrate that individual health goals, such as those discussed in the context of long-term care by family doctors and agreed upon by the patient and the doctor, are the more likely to be achieved the more closely they correspond to the implicit life tasks (Bahrs \& Henze, 2019). It requires a relationship based on understanding and mutual acceptance, in which the interlocutors can meet as subjects and take into account their particular contextual conditions. The dialogue aims at enabling the person seeking help to find individual solutions, extends the concept of shared decision-making (Elwyn et al., 2012), which is usually related to the agreedupon treatment plans, by the definition of the underlying problems and thus becomes an action-guiding philosophy. We show that this participatory approach helps to strengthen the sense of meaningfulness, and thus the SOC as a whole (Antonovsky, 1987). 
The chapter illustrates this process with a case study based on a series of four detailed family doctor-patient interviews (review dialogues) and a subsequent narrative interview lasting three hours. By systematically relating narrated life, experienced life and lived life to one another, we depict the process of forming resources and identity and illustrate its structuring function for the formation of relationships. It becomes clear that there is an inherent healing potential in the narration itself (Rosenthal, 1995; Nünning \& Nünning, 2019).

First, we outline specific features of the sixth decade of life with a particular focus on gender aspects. Further, we outline the selected theoretical aspects regarding our case study. We deal with the life course as a contradictory unit of socialization and individuation, which is mentally processed in the form of a biography. The life course is organized along with life phases and life tasks, the mastering of which is challenging and involves learning processes. These can be crisis-like, but it is precisely phases of transition that offer the chance to mature. The development of ego-identity and the relationship between identity and SOC are lifelong processes (Lindström \& Eriksson, 2010).

\section{Late Middle Age: Time for Stocktaking}

Preliminary note: the cited empirical results do not always refer precisely to the sixth decade of life. In the study by Lademann and Kolip (2005), for example, a broader age group between 45 and 65 years is considered. In their comparative study, Perrig and Höpflinger (2001) refer, amongst other things, to the age group of 50- to 55-year-olds.

\section{Particularities of the Sixth Decade of Life}

The life span between the 50th and 60th year of life is less clearly organized as a specific life phase than some earlier and later stages of life (Perrig-Chiello \& Perren, 2005). In this decade, the confrontation with illness, dying and death occurs more frequently, for example, through reports from the environment, illness or death of a family member. Concerning parents, the probability of care and nursing tasks increases (Höpflinger \& Perrig-Chiello, n.d.). Increasingly, physical limitations are becoming apparent, for example, at the level of sports or more general physical activities.

There are several specific health changes in the late middle age group, for example, the prevalence of many chronic diseases - such as skeletal and cariovascular diseases and cancer - are increasing (Lademann \& Kolip, 2005). Possible functional limitations also evoke a changed body life. This requires repeated repositioning of the attitude towards the body. It should be noted that the body is involved in percep- tion and communication and can be the object of observation and evaluation of one's perception and the perception of others. As the performer of the self, it also has a recursive effect on the self through its performance (Corbin \& Strauss, 1988, 2004 , p. $70-86$ ). According to Foucault, the body is produced through discursive practices. It is socially and culturally constructed. For example, scientific disciplines provide patterns of thinking or interpretation, which then become part of everyday knowledge and have an impact on action. This mediated knowledge influences how the body is spoken about in our society. Discourses are thus inseparably connected with power (Gugutzer, 2002, 2004). Since the body is also a significant factor in the self-value representation of the individual, constant identity work is required.

In the sixth decade of life, children will usually move out or have already left the parental home. The parents have to focus more strongly on themselves or the couple's relationship again and, if necessary, realigning oneself. Reasons for change often result from crisis-like events such as separation, divorce and loss of a loved one. In other areas of life, too, there is a stocktaking of the goals of life that are strived for, achieved and not achieved. The life priorities and plans of the past will become at the latest now a virulent and partly emotionally occupied topic. An example from two psychotherapeutic consultations - conducted by one of the authors - illustrate this:

Mrs. A., 55 years old: 'Now in the menopause, I have a growing feeling of physical insecurity, sometimes I sit there and have stomach aches, become thin-skinned and more vulnerable. Sometimes I feel guilty because of the breakdown of the relationship with my parents. My son is an adult, sometimes I think I should have done more for him, but I know it's over. Certain doors close.'

Here begins a reflexive and affective process of coming to terms with the situation, which - perhaps through mourning is an essential prerequisite for moving from passively resigned accepting of what happened to an integrative perspective or inner balance and experience of self-efficacy. Perhaps the result will be a similar insight as with Mrs. B.:

Mrs. B., 57 years old: 'My marriage is deadlocked, nothing more will happen. I was depressed often and for a long time, wondering how it came about. Then the thought came up: "What do I want to experience anymore?" So the thought came to me, "When one door closes, another opens." I began to reorient myself professionally.'

Against the background of increasing life expectancy, new challenges, fields of activity and responsibilities may arise, combined with the recognition that stable limits of previous life may be shifted. It can even be experienced as enriching and enjoyable to face new challenges. For example, grandchildren may enrich life towards the end of the decade.

Significant social and cultural dimensions influence the specific life situation or the design of life plans. These 
include, for example, growing income disparities, such as the level of education or access to education (Perrig-Chiello \& Höpflinger, 2001, p. 106).

\section{Gender}

Gender has a biological and social dimension, which is interrelated in the broadest sense. 'Gender' refers to sex in the sense of cultural, social or societal construction. It is expressed, for example, in the role of the sexes or gender identity. Gender construction affects social interactions and attributions from the beginning of the life course, and therefore gender-specific differences result in the respective phases of life.

Concerning the sex differences described in the following, it should be noted that other variables have a causal, moderating and differentiating effect, especially influences of socioeconomic status (education, occupation, income). Life situation, attitudes to health and the resulting behaviour diverge for gender groups (Backes, 1998; Backes \& Wolfinger, 2009).

Women, in particular, have to integrate family tasks and gainful employment and have more discontinuous career paths compared to men. Moreover, women are more likely to have jobs 'with less room for manoeuvre and autonomy' and are paid less for comparable work than men (Lademann \& Kolip, 2005, p. 81).

Looking at the sixth decade of those born between 1950 and 1959 on the basis of the German Ageing Survey (1996 to 2017), women are somewhat more satisfied with their lives than men during this phase. Satisfaction is highest at the beginning of the sixth decade and then decreases (Vogel et al., 2019, p. 14-15).

The drug consumption of women is comparatively higher, whereby hormone therapy playing a particularly relevant role during and after menopause. According to Lademann and Kolip (2005), its appropriateness must be questioned and partly interpreted as an indication of a tendency to medicalization.

Women are usually responsible for family health and more often make use of screening examinations and medical assistance (Robert Koch Institute, 2014; Beutel et al., 2019). Compared to men, affective disorders, anxiety disorders and somatoform disorders are more frequently diagnosed in women of the sixth decade of life. The most frequent cause of death in women is breast cancer (Lademann \& Kolip, 2005, p. 63-64).

Care work is unequally distributed between the sexes. In addition to caring for grandchildren, care activities include, in particular, the support and care of relatives. Concerning the cohort of those born between 1950 and 1959, there is a probability of care and nursing tasks of $23 \%$ for women and $16 \%$ for men (Vogel et al., 2009, p. 29).
The data of a representative telephone survey by the Robert Koch Institute (Wetzstein et al., 2015) confirm and complete the picture. According to these data, although the share of men providing nursing care is increasing, private home care is predominantly provided by women (Wetzstein et al., 2015, p. 3). The study does not make any specific statements for the sixth decade of life, but tendencies become apparent that are equally relevant for this age group. In general, about two-thirds of the carers across all age groups are women, and one third are men. As the extent of care increases, the share of women in the care of relatives increases (Wetzstein et al., 2015, p. 8). Nurses with a high level of care receive less social support than non-nurses, and the health status of carers is worse than that of non-carers.

The German Institute for Economic Research (DIW) has determined the importance of informal care in Germany for the years 2001 to 2012 and states that employed caregivers are more satisfied than non-employed caregivers, the satisfaction of caregivers is significantly lower compared to people who do not provide care and the general life satisfaction decreases with increasing care provision (Geyer \& Schulz, 2014, p. 299-300). Conversely generally applies: prerequisites for greater life satisfaction are 'good health resources and a low level of stressors such as chronic anxiety, social isolation and problems with the immediate family' (Perrig-Chiello \& Hutchison, 2010, p. 204).

The least willingness to care is found amongst people with high social status (Wetzstein et al., 2015, p. 8). Presumably, in contrast to families with a lower social status, they have more options at their disposal, such as the financed delegation of care tasks to third parties.

Care work, therefore, has many possible implications, such as restricted or (temporarily) abandoned employment, limited prevention opportunities, increased psychosocial burdens and limited options for realizing interests, needs and requirements. However, this probably does not concern care activities per se. Depending on the relationship with the person being cared for, work can also strengthen the SOC with meaningful and enriching experiences, experiences of satisfaction.

Men's life expectancy is shorter than that of women. In 2012 , men in the age group between 50 and 60 had a mortality risk that was at least 1.7-1.8 times higher. The mortality of unmarried men is higher than that of married men, that is, partnership or marriage, and family can act as protective resources or health-promoting context. Concerning diseases of the circulatory system, especially coronary heart disease (age group 45-65 years), there is a 2.9-fold excess mortality rate compared to women. Lung tumours, external causes (e.g. injuries, accidents) and diseases of the digestive and respiratory systems are comparatively more frequent causes of death in men (Lademann \& Kolip, 2005, p. 16; Robert Koch Institute, 2014). In a gender comparison, men display more frequent tobacco consumption, overweight and more 
inadequate nutritional behaviour. Health-endangering alcohol consumption is also higher amongst working men than amongst inactive men (Lademann \& Kolip, 2005, p. 41; Robert Koch Institute, 2014). Compared to women, men are more likely to have jobs with higher physical stress (Lademann \& Kolip, 2005, p. 81).

It is interesting to note that men's health awareness is much more developed than their health behaviour (Faltermaier, 2004). The development of health awareness may be counteracted by traditional concepts of self and masculinity that support 'risky' health behaviour, and corresponds to 'masculinity concepts'. If one pursues this aspect further and assumes that the definition of male identity continues to be strongly influenced by the professional role, then it should be noted that in the sixth decade, the forthcoming retirement with the expected loss of significance, status and relationships will cast its shadow. Often there are no alternative concepts to this. Instead, a mental and affective confrontation with the upcoming life changes is fended off.

\section{The Biography as a Learning Process}

The development of a human being can be understood as a contradictory unity of forming him/her into a member of society (socialization) and shaping his/her unique characteristics (individuation). In his concept of existential psychoanalysis, Sartre starts from a double birth of man, which he calls constitution (Sartre, 1977-1979, Vol. 1) and personalization (Sartre, 1977-1979, Vol. 2 and 3). On the one hand, man as a biological and social being finds himself in a world of social facts. Thus, body, history and environment determine a priori the chances for the social place that a person will be able to occupy and constitute a part of the social body: 'The meaning of life comes to the living person through the human society that sustains him and through the parents who engender him' (Sartre, 1981, p. 134). On the other hand, the social body reproduces and transforms itself through the social practice of the members of society who, through their designs, make themselves into individuals and thus, to a certain extent, occupy selfdefined places. 'To live is to produce meanings' (Sartre, 1981, p. 15).

Sartre - similar to Antonovsky regarding the SOC (Antonovsky, 1987) - assumes an autopoietic process. In every situation, man is confronted with a pre-structured world with various (thought and) action possibilities, which he cannot use simultaneously. He has to make choices (with always incomplete information), and thus at the same time invents the basic structure of his life project. Man first sets the values that define him. Nevertheless, the choice as a project in a self-structured world is, in turn, conditional. 'The basic behaviours are only accepted if they exist first' (Sartre, 1977-1979, Vol. 1, p. 53, translated by the authors). The constitution, as a meaningful body, is first conveyed in baby care. Although in this form of interaction, the actors refer particularly clearly to each other as 'whole people', the 'basic choice' as the attitude towards oneself and the world always concerns the psychosomatic unit and therefore has an affective structure. It indicates that 'hidden core(s) in which the experienced body and the sense mix' (Sartre, 1977-1979, Vol. 1, p. 56, translated by the authors).

Biography denotes 'the subjective construction or coherence formation of lived life'; it is the result of a 'conferring of meaning and significance' or 'the active performance of the subject through which the past is reorganized in the face of the present and the future' (Marotzki, 1990, p. 77). By their biography, which is continuously being newly constructed or changed, individuals simultaneously construct, reflect and develop drafts for action about the future perspective of life.

The biography is also 'the place where the individual processes of reflection and learning are synchronized' (MaierGutheil, 2015, p. 15). 'From a process perspective, experiences of everyday life, as well as crises, form potential triggers for learning activities' (Maier-Gutheil, 2015, p. 11), which can relate to attitudes, patterns of interpretation, experiences, self-awareness and resources. This happens in the most diverse learning contexts, such as family and relatives, leisure activities, job, sport, cultural and social gatherings and in contacts with professional helper systems, such as in the family-doctor relationship.

\section{Life Stages and Life Tasks}

Any age phase can be understood as a product of cultural representations, social constructions, social institutionalizations and structural principles as well as biological mechanisms. An order takes place through the life course, which is characterized by distinctive transitions and phases of life. In Kohli's sense, it is a system of rules built up over time (van Dyk, 2015, p. 48). As an example, the family life cycle is briefly sketched out here in line with Hegemann et al. (2000). It comprises key stages such as 'birth', 'early childhood', 'schooling', 'adolescence', 'early adult life with entry into the world of work, a transition to starting a family', 'bringing up children', 'midlife crisis with reassessments and reorientations', 'ageing', 'exit from working life', 'old age', 'very old age' and 'dying and death'.

With the increasing pluralization of life worlds, modernization and differentiation in postmodern societies, however, life courses are less structurally framed; there is a growing diversity of role patterns and individual design options (Eikelpasch \& Rademacher, 2004, p. 59; Bauman, 2001; Gilleard \& Higgs, 2019). Despite the growing flexibility of life courses, specific developmental tasks and challenges 
must be mastered in each of these phases against the background of corresponding risk and resource profiles. Therein, the here and now is not conceivable without the experienced past and the anticipated future.

The transitions or transitional periods between the respective phases are partly characterized by normative crises, which can be accompanied by severe challenges and instabilities. Transitions are 'life events that require coping with discontinuities on several levels, accelerate processes, stimulate intensified learning, and are perceived as significant biographical experiences of change in identity development' (Griebel \& Niesel, 2011, p. 37-38).

\section{Learning in Crises: Continuity and Break}

The transitions between development phases, life stages or life spans (Baltes, 1987) are associated with numerous new requirements. This refers to challenges such as integrating new roles and dealing with changing life contexts and self and identity issues (e.g. family changes and entry into or termination of working life) (Griebel \& Niesel, 2011, p. 37-38). It requires an intensified and accelerated learning process. Whilst anticipated grand-parenthood represents, for example, a positively experienced transition (Perrig-Chiello \& Perren, 2005, p. 178), tasks arising with the parents' need for care or accompanying the dying mother/father are very stressful or ambivalent (Perrig-Chiello \& Höpflinger, 2001, p. 106).

Crisis events beyond transitions can, of course, occur at any time and within any phase of life. The reasons can be strokes of fate, such as the loss of essential caregivers or the occurrence of severe illness or misfortune at work, break-up of relationships and much more. Even seemingly processed previous life experiences, conflicts and crises can then become virulent again, and existing certainties and an inner sense of security can dissolve. On an individual level, initial denial tendencies and affects such as grief, fears, helplessness, excessive demands, stagnation, helplessness and hopelessness, as well as body-related complaints, can occur. At the same time, in the sense of a learning process, the crisis opens up an opportunity for developmental steps by acceptance (e.g. of limits to the controllability of life; Lindström \& Eriksson, 2010, p. 13) balancing and reflexive processing of the past life, the here and now and the view of the presumed future. The balancing does not only refer to supposedly missed chances and failures but also to experiences that represent abilities or growth potentials, where one experienced satisfaction or pride. Ideally, the image of a realm of possibilities can emerge, combined with an experience of one's potentials (and limitations) as well as emerging needs and desires: Do I now want to change something in and about the previous life model? If so, what? How could I start to realize this?

\section{Identity, SOC and Life Cycle}

According to Antonovsky (1979, p. 110), ego-identity plays a central role in the field of generalized resistance resources. Ego-identity can be understood concerning the subject as an inner, interactive and constant process of everyday identity work. It is regulative that makes it possible to experience oneself as 'the same' in different social situations, and it is constantly re-established in interaction with other subjects. However, it is also a (self-)attribution that can be recognized by third parties, through which the person remains recognizable as identical in different situations (and is thus reliable). For this, several competencies must be acquired, including the ability to fill the contradictions of life with meaning and to synthesize them. This development is interactive and takes place against the background of societal, social and cultural conditions (Bohleber, 1997; Höfer, 2006; Keupp, 1997; Keupp et al., 2006; Krappmann, 1975, 1997).

An important question is how the relationship between ego-identity development and the SOC could look like. Höfer (2006) has attempted to analyse this. Before we describe her considerations, the SOC will be outlined in short.

In the salutogenic model, the sense of coherence (SOC) is of central importance. According to Antonovsky, it is composed of three dimensions, comprehensibility, manageability and meaningfulness, and it is a general and profound life orientation. It is a 'dispositional orientation rather than a response to a specific situation' (Antonovsky, 1987, p. 75). The SOC represents 'the extent to which one has a pervasive enduring though dynamic feeling of confidence that (1) the stimuli deriving from one's internal and external environments in the course of living are structured, predictable and explicable (2) the resources are available to one to meet the demands posed by these stimuli; and (3) these demands are challenges, worthy of investment and engagement' (Antonovsky, 1987, p. 19). The SOC is developing based on life experiences such as 'experiences of consistency, participation in decisions and a balance between demands and resources' (Faltermaier, 2006, p. 190; Antonovsky, 1987). In contrast to Antonovsky's early, but later modified, hypothesis, the SOC seems to have developmental potential beyond the age of 30 and is even expected to increase in the further course of life (Lindström \& Eriksson, 2010, p. 23-25). In this respect, the SOC represents a dynamic process not only in childhood and youth but also in later life cycles.

Höfer (2006) conceptualizes 'identity as a source of the feeling of coherence' (2006, p. 57). It represents a 'reflexive frame of reference' within which the individual deals with his or her own life, for example, and attempts to 'develop coherent passages of internal and external demands' (Höfer, 2006 , p. 60). SOC is formed on evaluations of how everyday 
demands are dealt with and expresses, as Antonovsky (1979) puts it, the relationship to the world (Höfer, 2006, p. 62). In Höfer's view, the SOC is the result of many successful identity-shaping experiences. The better the subject succeeds in creating 'links in his projects and experiences the project designs as subjectively coherent and authentic, the stronger the SOC will be' (Höfer, 2006, p. 63). One may assume that there will also be a positive feedback effect from the SOC on the feeling of identity.

\section{Salutogenesis as Relationship-Related Health Development and Learning Process}

The development of identity and the SOC takes rise within the framework of processes of interaction and social exchange (Antonovsky, 1987, p. 92-94). These processes last a whole lifetime and are never completed (Lindström \& Eriksson, 2010). How this connection is formed is specific to the individual, and it is expressed in one's relationship to the world as a whole, in one's relationship to others and in relation to oneself (especially one's body). This specific style can also be expressed in health and illness behaviour as well as in the formation of symptoms, insofar as these are understood as part of a communicative process and can be attributed as active contributions (Sartre, 1977-1979; Weizsäcker, 1956; Uexküll, 2004).

Although the formation of health is designed as a result of self-regulation, professional support is required in special cases. In the fields of care, counselling, therapy and (family) practice, the relationship between the (two) actors is also of central importance. If the person seeking help feels taken seriously and appreciated as a person when interacting with a professional contact person, he/she can also experience him/herself and his/her relationships in a new way. He/she learns to make use of previously unknown resources and can subsequently test and stabilize the development potential in everyday life.

The long-term care of (healthy and) sick people requires a hermeneutic case understanding, taking somatic, psychosocial, sociocultural and ecological aspects into consideration. Hermeneutic case understanding is 'a specific professional activity, which is patient-centered, contextrelated, biographical and within a joint interpretive community (inclusion of the patient's concept of illness) and has a case-specific individual result' (Bahrs, 2012, p. 356).

Striving for a trusting, cooperative and open relationship includes, for example: establishing a stable work alliance, continuous cooperation, active listening, trying to understand the patients and their (family) life situation as well as an orientation towards his resources and strengths (cf. Honermann et al., 1999). A fundamental acceptance of the patients as experts of themselves promotes all three components of the help-seeking person's SOC.

\section{Case Study: 'I Have Lost Sight of My Goal'}

If you ask people about the most important thing in their lives, many will say: 'Health.' On closer listening, it quickly becomes apparent that the respective meaning of health is individual (Matthiessen, 2010; Sturmberg et al., 2019).

What is called and desired as 'health' is by no means arbitrary. We are all born into a particular, historically grown cultural and social environment so that this framework already shapes many of our perceptions and feelings in everyday life and social relationships. Against this background, we learn to interpret our own physically mediated experiences, to perceive signs of well-being and discomfort in ourselves and others and to differentiate more and more between ideas of desirable 'health' and 'illness'. What we consider to be 'healthy' and 'ill' is thus also an expression and result of a social learning experience (Payer, 1993; Faltermaier, 2009; Helmich et al., 1991) and relates to social developmental tasks faced by the individual (Buddeberg, 2003).

In this learning process, there are always situations in which the participants have different views on whether or not a behaviour or condition should be assessed as 'sick' or 'healthy'. According to this, 'health' is not an inherent fixed characteristic of the person, but rather the result of negotiations taking place in interpersonal relationships (Balint, 1957). Health is (also) between people, and thus social 'treatment' is also required to contribute to social recovery (Weizsäcker, 1930).

The development of the SOC is mediated through social relations and social interaction. Every human being has developmental potentials (GRR) from birth and learns to use these potentials (or is hindered in doing so) through interaction with the social environment (Antonovsky, 1987). The development of the SOC is, therefore, a lifelong process in which the primary caregivers (family) play a central role, which is later supplemented and/or temporarily replaced by other supporting persons in the social environment (family, friends, colleagues) and professional helpers. They can promote the further development of the SOC, especially in accompanying transitional crises. But to bring about sustainable change, it is necessary to expand the opportunities for influencing the shaping of one's own living conditions. A vital catalyst can be the family doctor, who plays the role of an 'elective relative' for many people.

Family doctors are often the first point of contact for health issues, and they often treat family members and people from social neighbourhoods over a long time. Therefore, patients and doctors usually assume that they know each other well and act following their respective needs. Admittedly, essential aspects - especially psychosocial 
aspects - regularly remain unaddressed. The patient and the doctor attribute to each other - often unnoticed by both - that the other person does not want to discuss this or is unable to do so - likewise an 'agreement in misunderstanding' (Brucks et al., 1998, p. 43). Thus, it is not discussed what health means for the patient and if or how it is worthwhile for him/ her to be healthy or to become healthy again (Bahrs \& Matthiessen, 2007). The treatment thus becomes a routine act, which is carried out like a ritual (Balint, 1975).

The long-term care of chronically ill people is a significant challenge for the doctor-patient relationship. This challenge pertains, at least implicitly, to all relevant areas of the life of the patient and his or her social and family network. As a rule, long-term care includes spontaneous treatment related to an acute problem on the one hand and regular, quasi-ritualized checks concerning diagnosed chronic diseases with an already established treatment regime on the other. However, there is no 'natural point in time' to reflect on the various aspects together to enable comprehensive treatment; a conversation setting is required that is free from acute pressure to act and well-established routines. The instrument of review dialogue (RD) offers the opportunity to leave the routines, to assess the significance of already known facts and to gain new insights into relevant life contexts and so to win a comprehensive understanding of the patient in terms of an 'overall diagnosis' (Balint, 1957).

The review dialogue was developed in a model project (Bahrs \& Matthiessen, 2007, Bahrs, 2011a; Rojatz et al. in Chap. 38 in this book). In the trial phase, general practitioners specifically invited some patients with chronic illnesses outside of the usual consultation hours for a 20- to 30-minute conversation to develop jointly an understanding of the overall situation. Furthermore, the aim was to find out one or two health goals relevant to the patients and to develop jointly an individual treatment plan tailored to these goals. The development was regularly reviewed in three further meetings in the following year; successes were acknowledged and, if necessary, the goals were modified, or new ways of achieving them were looked for (Bahrs, 2011b).

The following example is based on four consecutive videotaped review dialogues and additional information from a three-hour biographical interview with the patient. The review dialogues (Table 18.1) took place in 2012/2013

Table 18.1 Health goals and their development over time (Bahrs et al., 2017)

\begin{tabular}{|c|c|c|c|c|}
\hline Review dialogue & I (June 2012) & II (October 2012) & III (January 2013) & IV (July 2013) \\
\hline Symptoms & $\begin{array}{l}\text { Back pain, } \\
\text { visual disturbances }\end{array}$ & Complaints without organic findings & $\begin{array}{l}\text { Feeling for own } \\
\text { body lost }\end{array}$ & $\begin{array}{l}\text { Visual disturbances, } \\
\text { tensions }\end{array}$ \\
\hline Topics & $\begin{array}{l}\text { Care for the father, } \\
\text { emotional support for the } \\
\text { mother }\end{array}$ & $\begin{array}{l}\text { Father has been diagnosed with } \\
\text { incurable cancer }\end{array}$ & $\begin{array}{l}\text { Organization of } \\
\text { palliative care for } \\
\text { father and } \\
\text { emotional support } \\
\text { for mother }\end{array}$ & $\begin{array}{l}\text { Father has died } \rightarrow \\
\text { supporting the mother, } \\
\text { mourning }\end{array}$ \\
\hline \multirow[t]{2}{*}{$\begin{array}{l}\text { Agreed health } \\
\text { goals }\end{array}$} & 1. Less pain in movement & \multirow{2}{*}{$\begin{array}{l}\text { 'Total package' (feel better and more } \\
\text { relaxed in the body, less pain, become } \\
\text { aware of one's capabilities) }\end{array}$} & 1. Improve fitness & $\begin{array}{l}\text { 1. Improve fitness and } \\
\text { movement }\end{array}$ \\
\hline & 2. Improve vision & & $\begin{array}{l}\text { 2. Be aware of } \\
\text { one's capabilities }\end{array}$ & 2. Decrease stress \\
\hline $\begin{array}{l}\text { Success } \\
\text { concerning the } \\
\text { achievement of } \\
\text { health goals }\end{array}$ & & $\begin{array}{l}\text { Less pain; visual problems remain } \\
\text { unchanged }\end{array}$ & $\begin{array}{l}\text { Improved mobility, } \\
\text { aid is organized }\end{array}$ & $\begin{array}{l}\text { Death of the father, } \\
\text { self-care is hardly possible }\end{array}$ \\
\hline $\begin{array}{l}\text { Developmental } \\
\text { task }\end{array}$ & $\begin{array}{l}\text { Respect the autonomy of } \\
\text { both (parents and oneself), } \\
\text { pledge support }\end{array}$ & Acknowledge limitations, accept help & $\begin{array}{l}\text { Prepare to say } \\
\text { goodbye, secure aid } \\
\text { and take care of } \\
\text { oneself }\end{array}$ & $\begin{array}{l}\text { Mourning, prepare for } \\
\text { new projects }\end{array}$ \\
\hline $\begin{array}{l}\text { GP's significant } \\
\text { intervention/flash }\end{array}$ & $\begin{array}{l}\text { 'You have an enormous } \\
\text { sense of duty. You could } \\
\text { have said: "Mum, you } \\
\text { know what, you move into } \\
\text { sheltered living and see } \\
\text { who's taking care of you!" } \\
\text { Of course, you can't do } \\
\text { that. When I hear you talk } \\
\text { about your backaches, I } \\
\text { think, 'This woman has a } \\
\text { heavy load to bear"', }\end{array}$ & $\begin{array}{l}\text { 'A health goal can be to ensure that } \\
\text { you are doing well and that you make } \\
\text { good decisions. That you don't unpack } \\
\text { everything and you don't say, "'Okay, } \\
\text { next job, next job, next job.' Instead, } \\
\text { you take a closer look at your own } \\
\text { limitations' }\end{array}$ & $\begin{array}{l}\text { 'You're a family of } \\
\text { caring women' }\end{array}$ & $\begin{array}{l}\text { 'Whenever you want to } \\
\text { move forward and } \\
\text { develop, there is } \\
\text { something physical, that } \\
\text { stops you. And then you } \\
\text { stay with your mother' }\end{array}$ \\
\hline Metaphor & $\begin{array}{l}\text { 'My mother follows me } \\
\text { like a shadow' }\end{array}$ & 'I'm afraid not to come back again' & $\begin{array}{l}\text { 'I feel totally let } \\
\text { down' }\end{array}$ & $\begin{array}{l}\text { 'My vision is blurred, and } \\
\text { I don't want to have to } \\
\text { live with that anymore' }\end{array}$ \\
\hline
\end{tabular}


within the framework of the BALANCE project (Bahrs et al., 2015, 2017).

Dr. Angela Mead ${ }^{1}$ is 50 years old and has been a general practitioner for 12 years. Since then, she has known her patient Mrs. Pamela Smith, 58 years old, an engineer by profession, having been a housewife for about 20 years and now working as a freelance archery trainer. She is married to Mr. John Smith, a 62-year-old hard-working academic who appears to be in good health and is described as a 'centre of tranquillity'. Pamela Smith visits her doctor about once a month, often because of back pain. Dr. Mead also treats Mrs. Smith's parents Mary and Martin Philipp. Both live, albeit in their apartment, in the same house as Mrs. Smith. The 87-year-old Martin Philipp has been suffering from type I diabetes for many years, which he has managed well with the support of his wife. In the meantime, dementia has developed, the need for care has grown and 82-year-old Mary Philipp now also needs the help of her daughter, Pamela Smith. Dr. Mead knows the other family members - the two sons Gerald and Thomas, who are already studying, and the husband Johann Smith - from sporadic encounters.

\section{A Brief Characterization of the Encounters}

\section{Review Dialogue I: Problem outline: current situation, chal-} lenges and development task

In the first review dialogue, Mrs. Smith complains of back pain and visual disturbances, which massively restrict her mobility and frighten her. She comments on her situation, which is dominated by caring for her mother and father. Since early childhood, she was significantly influenced by her mother's panic attacks: 'My mother is like a shadow'. Although Dr. Mead knows and treats the entire family, the mother-daughter constellation has never been an issue of the consultations with the family doctor. The general practitioner learns that Mrs. Smith's main development task is one of attaining autonomy and not the support of her parents. Although both actors are aware of this fundamental problem, this is not reflected in their prioritization of the two primary health objectives. These relate instead to the physical complaints, which usually would be treated by specialists (orthopaedist/physiotherapist, ophthalmologist).

Review Dialogue II: The body is taking part in the communication: the need for self-protection and defining one's own health goals

Medical examinations in the following three months do not show any organic findings for Pamela's complaints. But Mrs. Smith reports a reduction in her back pain resulting from physiotherapy, but an increase in new problems for

${ }^{1}$ All names and other personal identifiers in the case study have been changed to protect privacy and confidentiality. which no physical or organic cause can be found. She narrates on the diagnosis of an incurable carcinoma in her father and her lack of care for herself. Her mother does not understand the situation and Mrs. Smith is left alone regarding the organization of her father's care. Instantly, Dr. Mead suggests that the already agreed health goals (less pain in movement and improved vision) should be supplemented to include the importance of self-awareness and empowerment ('total package'). She supports Pamela Smith's insight that it is crucial to perceive and recognize one's limitations and to allow help. Pamela Smith's homework is to pay attention to her strengths.

Review Dialogue III: Farewell, mourning, setting limits, relief and hope for new beginnings

Mrs. Smith seems to progress. Having organized outpatient palliative care for her father, emotional support for her mother and body therapy (acupuncture) for herself, she has become physically more mobile again. She acknowledges the painful reality and prepares for the imminent farewell to her father's death. Because of the experienced help, she can imagine a further development of the mother-daughter relationship, which releases both of them from their mutual dependence. Nevertheless, Pamela worries that her mother might be overwhelmed by the care of the dying father. The mother cannot yet come to terms with the situation and believes - following a family-mediated ethical imperative that she has to cope with everything herself. Dr. Mead points out that in this 'family of caring women' all women tend to overtax themselves. 'You are very close to it, aren't you?' The doctor now directs attention to relaxation possibilities and lets Pamela find legitimate and necessary free space for herself with her artistic activities on the one hand and with indispositions on the other. Although it is difficult for her to attend and support her dying father, Mrs. Smith is optimistic regarding the future.

Review Dialogue IV: Being thrown back and ambivalence

However, the hope for structural change is deceptive. Mrs. Smith reports that on his deathbed, her father obliged her to look after her mother. Mary Philipp also loses her independence after her husband's death. Again, Pamela Smith suffers from tension, cardiac arrhythmia and visual problems without any apparent physical causes. Her father has passed on in the meantime, and her mother now needs her intensive support. Mrs. Smith is fundamentally concerned about her eye problems: 'My vision is blurred, and I don't want to have to live with that.' Dr. Mead draws a line between Mrs. Smith's attempts to increase her independence, her increase in pain and physical symptoms and her remaining with her mother. Dr. Mead suggests seeking professional psychotherapeutic support, but Mrs. Smith rejects this idea and shows interest in further review dialogues with Dr. Mead. 
The pattern of the mother-daughter relationship, which has been established for more than 50 years, apparently cannot be abandoned. For all her resentment about her domestic situation, Pamela Smith seems to prefer the security of the ever-same to the uncertainties that come with a change.

Pamela Smith has developed remarkable self-help potentials and makes full use of these resources. With Qi Gong and dance, she uses body-oriented offers that promote mindfulness and enable social support in groups. She is active as an artist and is also successful in this. What all these activities have in common is that Pamela gets into a flow and creates a new reality for herself for a limited time, in which she can transcend the boundaries that are so obvious in everyday life.

However, she has to return to this everyday life again and again, and so she will probably continue to depend on the help of Dr. Mead.

\section{Health Goals and Biographical Development Tasks in the Course of the Review Dialogues}

As usual in primary care, the starting point of any treatment is the physical complaints presented by the patient. In the first review dialogue, Dr. Mead initially assumes difficulties in the current family situation as a background for Mrs. Smith's raw feeling of tension. However, Mrs. Smith sees her husband and her sons as havens of tranquillity. Problems and stress are connected to her family of origin.
Caring for elderly family members is a typical development task for Mrs. Smith's present life stage. Both the development task, in general, and Mrs. Smith's living situation, in particular, are well known to Dr. Mead. However, the doctor unexpectedly becomes aware of the interdependence between Mrs. Smith and her parents, a situation that has existed from her childhood to the present. Detachment from the mother remains a development task to be attained in the future. The phrase 'we are a double-pack' reveals the severance of her dependence and lack of respect ('flash', (Balint \& Norell, 1975)). Further, Mrs. Smith missed a socially competent mother in her childhood and adolescence who would promote her self-development extensively. Therefore, she has only been able to attain her goals to a limited extent across the developmental phases, such as self-confidence and security, autonomy and detachment from early bonds.

The 'in-between' in this family are characterized in particular by anxiety, which characterizes the family atmosphere as a whole (GRD) and is expressed in different ways by several members of the family (family SOC; see Vossler, 2001, Braun-Lewensohn et al., 2017) (Table 18.2). The panic attacks of her mother are caused by traumatizing war experiences which seems to be a silenced taboo: 'The worst was actually that my mother did not confess it. It happened already when I was a child. Nobody could ever know that. Even we children did not know what was going on.' (Review Dialogue I).

Mrs. Smith suffered from panic attacks during her studies, whilst her son, later on, develops similar symptoms from

Table 18.2 Diseases/illnesses across the life span

\begin{tabular}{l|l|l|l|l|l}
\hline $\begin{array}{l}\text { Development } \\
\text { phase }\end{array}$ & $\begin{array}{l}\text { Diagnosis according } \\
\text { to the patient }\end{array}$ & Treatment & Important life data & $\begin{array}{l}\text { Expressive } \\
\text { content }\end{array}$ \\
\hline $\begin{array}{l}\text { Childhood } \\
\text { and youth }(<\end{array}$ & Scoliosis & $\begin{array}{l}\text { Gypsum bed and } \\
\text { physiotherapy }\end{array}$ & $\begin{array}{l}\text { Panic attacks of } \\
\text { the mother }\end{array}$ & $\begin{array}{l}\text { Structural overload in care, role reversal } \\
\text { daughter/mother } \\
\text { Back problems as 'birth defect' } \\
\text { Back strengthening required }\end{array}$ & $\begin{array}{l}\text { Structural } \\
\text { lack of back } \\
\text { support }\end{array}$ \\
\hline $\begin{array}{l}\text { Young } \\
\text { adulthood } \\
\left(\begin{array}{l}20-35) \\
\text { and }\end{array}\right.\end{array}$ & $\begin{array}{l}\text { Panic attacks; } \\
\text { arrhythmias }\end{array}$ & Talk therapy & $\begin{array}{l}\text { Strenuous } \\
\text { studies; } \\
\text { separation from } \\
\text { a partner }\end{array}$ & $\begin{array}{l}\text { Recognition through performance is no } \\
\text { longer sufficient; insult (rejection by the } \\
\text { partner and his family and thus } \\
\text { simultaneously the separation from the } \\
\text { family of origin fails ('heartache') }\end{array}$ & $\begin{array}{l}\text { Fear of failure } \\
\text { and loss of } \\
\text { face }\end{array}$ \\
\hline $\begin{array}{l}\text { Middle } \\
\text { adulthood } \\
\text { (approx. } \\
\text { 35-50) }\end{array}$ & $\begin{array}{l}\text { Disc prolapse; } \\
\text { sinusitis; fears of } \\
\text { the oldest son }\end{array}$ & $\begin{array}{l}\text { General } \\
\text { practitioner, } \\
\text { specialists; talk } \\
\text { therapist }\end{array}$ & $\begin{array}{l}\text { Birth of children; } \\
\text { being no longer } \\
\text { in work }\end{array}$ & $\begin{array}{l}\text { Constitutional 'deficiency' and permanent } \\
\text { overstrain are reflected in organic damage } \\
\text { and massive crises }\end{array}$ & Body strike \\
\hline $\begin{array}{l}\text { Mature } \\
\text { (from 50) }\end{array}$ & $\begin{array}{l}\text { Iritis; disc prolapse; } \\
\text { hip necrosis (or } \\
\text { arthrosis?); } \\
\text { sinusitis; mitral } \\
\text { valve collapse }\end{array}$ & $\begin{array}{l}\text { General } \\
\text { practitioner, } \\
\text { specialist; } \\
\text { alternative therapy }\end{array}$ & $\begin{array}{l}\text { The eldest son } \\
\text { leaves home; the } \\
\text { parents need care } \\
\text { End-of-life care } \\
\text { for father } \\
\text { (cancer) and } \\
\text { emotional } \\
\text { support for } \\
\text { mother }\end{array}$ & $\begin{array}{l}\text { Accompanying the dying father (cancer) } \\
\text { and emotional support for the mother. } \\
\text { Extending and intensifying multiple } \\
\text { physical complaints and impairment of } \\
\text { perception (vision) and movement. } \\
\text { Comprehensive insecurity (no physical } \\
\text { feeling, goal lost) }\end{array}$ & $\begin{array}{l}\text { Restriction of } \\
\text { perception } \\
\text { and } \\
\text { movement }\end{array}$ \\
\hline
\end{tabular}

Modified following Bahrs et al. (2017) 
time to time during school lessons. Both her son and herself improved through talk psychotherapy (SRR). Mrs. Smith's manifold physical complaints, however, are connected to her occurring fear, and the repeated investigations remain fruitless in the long term. Nevertheless, the investigation is effective in terms of short-term treatments, and Mrs. Smith feels fine. This intervention expands physical exclusion diagnostics: it is based on personal recognition and a biographical understanding (GRR).

Support has its limits where the predominance of the family task cannot be resolved by reflection. When the father on his deathbed commits Pamela Smith once again to taking care of her mother, the family force field is restaged, which Pamela Smith can hardly escape.

And my father then somehow did a tiny ceremony. (...) But he just said, 'I promise with all my heart and all my hand', but I don't know what? And then he shook hands with everyone. (...) He tried terribly hard. (...) But I actually thought that it was really important to let someone go. (...) He can't really only leave after we have said that we would take care of our mother and it would all be done, he doesn't need to worry (crying). (Biographical interview)

\section{The Body as Mediator}

In the following, we assume that the body has a double function. It mediates between inner and outer demands and is the gateway to and part of the environment and the world around us. On the one hand, the body can be regarded as a thing amongst things, as a machine, so to speak, which controls itself according to describable rules. On the other hand, it can be seen as interpreting and expressing carrier of meaning, in which social rules are inscribed, manifested, expressed and reinvented. The self-regulation and impression/expression of the living body (Leib) are the result of a continuous learning process, with the SOC acting as its virtual coordination centre. This learning process is also expressed in the history of symptom formation. The reconstruction of the formation of symptoms in the context of life history is therefore also a key to understanding the world view (and thus to the development of the SOC).

The following description is hypothetical. We cannot describe in detail the relationship between biography, symptom formation and the development of coping mechanisms in the whole life course of Mrs. Smith. However, we have put information from the various documented conversations into a mental order that takes up the patient's self-interpretations, the doctor's interpretations and our reflections. This is intended to illustrate a possible development on a case-by-case basis.

Since the peculiarities of the sixth decade of life are based on the increase of meaning in the course of life and cannot be understood if one does not think of the preceding experiences, we follow the process as a whole.

In her childhood, Pamela experiences perception and interpretation of physical phenomena in the mirror of her environment. Thus, Pamela Smith's back problems are interpreted as a (congenital) malposition (scoliosis), which has to be 'straightened out' via plaster bed and physiotherapy. A retrospective alternative interpretation could be that the child, carrying a heavy load, has a hard time getting into an upright position from the beginning and needs continuous support.

In young adulthood, the body increasingly becomes a means of perception and expression, which is gradually and consciously acquired. Pamela Smith speaks about this time as having panic attacks, nervousness and heartache, which are associated with high-performance requirements in a maledominated study and with an insulting separation from the life partner. She must become aware of the expressive content of the body's events in the therapeutic dialogue. Although she describes the conversations as helpful, she sees the central support above all in the helpful attitude of the (future) husband, that is, especially not in a therapeutic relationship.

In adulthood, following pregnancy and birth, back problems reappear, now in the area of the cervical spine and accompanied by temporary numbness in the face. Metaphorically speaking, fainting and loss of face could be associated with this - but any of the participants does not express such thoughts. The overwhelming effect, however, becomes practically tangible. What had been described as a structural weakness in childhood, but not perceived as suffering, now becomes painfully acute and calls urgently for treatment and a change of attitude. This is expressed in giving up one's job and changing roles. The underlying distress is not felt by Pamela but is delayed and communicated via her son's fears.

In late adulthood, the variety and intensity of the symptoms increase. In temporal connection with the increasing need for care of the parents, vision problems occur, which particularly frighten Pamela Smith, because she 'is a person who does it with her eyes' (Review Dialogue I). Due to a renewed herniated disc and hip problems, she is also severely impaired in her mobility. Heart rhythm disturbances and stomach problems direct attention inwards and Pamela Smith becomes a problem altogether: 'I am a terribly nervous shit' (Biographical interview). The complaints call for a rethinking of the family division of labour and the self-perceived mission. However, Pamela Smith cannot draw the obvious conclusions from this. At her father's deathbed, she is once again obliged to care for her family, so that her freedom of self-definition proves to be limited. The doctor raises the question whether 'whenever you want to go forward on your own, what physical stops you? And then you stay with your mother?' (Review Dialogue IV). Since 
real independence from her mother is not possible, Mrs. Smith is referred to a virtual reality (painting) in which she invents herself grandiosely and thus, in a way, exceeds the physical limits.

Using the example of back problems, we summarize the formation of the body and the attribution of meaning (Leder, 1990). The formation of symptoms is a simultaneous process of illness and recovery, as well as the emergence of resistance deficits and the development of resources. Back problems accompany Pamela Smith throughout her life. Diagnoses such as scoliosis or pelvic obliquity indicate structural problems (GRD) whose effects can at best be limited by physiotherapy (SRR). As an adult, Pamela Smith learns that dance and Taiji not only encourage movement (SRR) but are also fun and convivial (GRR). Her sister, a physiotherapist, emphasizes the success: 'I never thought you would get your back so straight again' (Biographical interview) (SRR $\rightarrow \mathrm{GRR} \rightarrow \mathrm{SOC})$. Increasingly, however, Pamela Smith has to accept that she can only influence the healing process to a limited extent (GRD) and that the muscles temporarily work against each other (SRD). This tension can be seen as an expression of a lack of fit between internal and external demands (Uexküll, 2004). The general practitioner states: 'The muscular system is the largest sensory organ of the body. All feelings, tension, external influences, and internal influences are also mediated via the muscle fibers.' Interpreting posture in a broader sense (SOC), the doctor advises a fundamental change of attitude (GRR). Pamela Smith looks for therapeutic support in the complementary medical field (acupuncture) (SRR) and benefits in particular from her self-chosen hobby, painting
$(\mathrm{SRR} \rightarrow$ GRR). "When I paint, when I am somehow switched off, I am complete with myself. (...) I am then simply beamed away' (Biographical interview) (SRR $\rightarrow$ GRR $\rightarrow$ SOC).

The corporeal history includes the formation of the body as well as the development of resources. So, we would like to emphasize that Pamela Smith has considerable personal (resistance) resources (Antonovsky, 1987). She is ambitious and persistent as we can learn from her educational, professional and sports development. She is creative as well, expressing her point of view by painting, dancing, and her love for music. Having done Taiji exercise for 20 years, she is reflective and sensitive to her physical reactions.

In conclusion, she conceptualizes health and illness in a differentiated way. She organizes herself and gains support through her laity system (friends and colleagues) and professionals in her complementary and biomedical system. Additionally, she manages to apply the philosophy of the review dialogues, wondering what she has said: 'I cannot see the goal at archery.' Becoming aware of the underlying meaning of her wording, she concludes that she has to ask again: 'What are my life goals?' (Review Dialogue IV).

\section{Development of the SOC in the Life Course}

Antonovsky regarded consistency, a good load balance and participation in shaping the outcome as crucial for the development of the SOC (Antonovsky, 1987, 92). In this perspective, we can imagine the development of the SOC in the case of Pamela Smith roughly as follows (see Table 18.3):

Table 18.3 Resource development across the life span

\begin{tabular}{l|l|l|l|l|l}
\hline $\begin{array}{l}\text { Development } \\
\text { phase }\end{array}$ & $\begin{array}{l}\text { Symptom formation as a } \\
\text { Important life date }\end{array}$ & $\begin{array}{l}\text { Generalized resistance } \\
\text { adaptive process }\end{array}$ & $\begin{array}{l}\text { Specific resistance } \\
\text { resources (GRR) }\end{array}$ & SOC \\
\hline $\begin{array}{l}\text { Childhood } \\
\text { and youth }(<)\end{array}$ & $\begin{array}{l}\text { Growing up in a } \\
\text { city in an industrial } \\
\text { region; 5-year } \\
\text { younger sister } \\
\begin{array}{l}\text { Secondary school } \\
\text { and apprenticeship; } \\
\text { panic attacks of the } \\
\text { mother - parents } \\
\text { war children }\end{array}\end{array}$ & No information & $\begin{array}{l}\text { Secondary school, } \\
\text { apprenticeship, } \\
\text { technical secondary } \\
\text { school } \\
\text { Younger sister starts } \\
\text { studying directly at } \\
\text { about the same time } \\
\text { Finances: rather tight }\end{array}$ & $\begin{array}{l}\text { Back gymnastics } \\
\text { Technical secondary } \\
\text { school }\end{array}$ & $\begin{array}{l}\text { Comprehensibility: clear } \\
\text { rules about role } \\
\text { behaviour, but the } \\
\text { background cannot be } \\
\text { addressed (latently } \\
\text { diffuse) } \\
\text { Manageability: tends to } \\
\text { be overburdening } \\
\text { Meaningfulness: } \\
\text { (relatively low) } \\
\text { Participation: } \\
\text { relatively little } \\
\text { Emotional closeness: } \\
\text { not with the mother, } \\
\text { maybe with the father, } \\
\text { possibly with the sister }\end{array}$ \\
& & & & & \\
\hline
\end{tabular}


Table 18.3 (continued)

\begin{tabular}{|c|c|c|c|c|c|}
\hline $\begin{array}{l}\text { Development } \\
\text { phase }\end{array}$ & Important life date & $\begin{array}{l}\text { Symptom formation as an } \\
\text { adaptive process }\end{array}$ & $\begin{array}{l}\text { Generalized resistance } \\
\text { resources (GRR) }\end{array}$ & $\begin{array}{l}\text { Specific resistance } \\
\text { resources (SRR) }\end{array}$ & SOC \\
\hline $\begin{array}{l}\text { Young } \\
\text { adulthood } \\
(20-35)\end{array}$ & $\begin{array}{l}\text { Study and work in } \\
\text { a male-dominated } \\
\text { field of work; } \\
\text { (humiliating) } \\
\text { partner separation }\end{array}$ & $\begin{array}{l}\text { Development of } \\
\text { autonomy as a challenge } \\
\text { and excessive demand; } \\
\text { social limitation creates } \\
\text { fear, which is physically } \\
\text { felt and expressed as } \\
\text { well as withdrawn from } \\
\text { being addressed }\end{array}$ & $\begin{array}{l}\text { Access to university } \\
\text { on the second } \\
\text { educational pathway, } \\
\text { studying }\end{array}$ & $\begin{array}{l}\text { Successful use of talk } \\
\text { therapy } \\
\text { The new partner is } \\
\text { helpful }\end{array}$ & $\begin{array}{l}\text { Comprehensibility: } \\
\text { unclear; fails in } \\
\text { interaction with a milieu } \\
\text { foreign to her } \\
\text { Manageability: } \\
\text { enormous performance } \\
\text { despite obstacles } \\
\text { Meaningfulness: critical } \\
\text { Participation: (follows } \\
\text { the marked path) } \\
\text { Emotional closeness: } \\
\text { critical }\end{array}$ \\
\hline $\begin{array}{l}\text { Middle } \\
\text { adulthood } \\
\text { (approx. } \\
35-50 \text { ) }\end{array}$ & $\begin{array}{l}\text { Birth of children; } \\
\text { being no longer in } \\
\text { work: change of } \\
\text { roles/compromise } \\
\text { (no 'male' career) } \\
\text { Living with the } \\
\text { parents }\end{array}$ & $\begin{array}{l}\text { The shift of fear to the } \\
\text { body and other family } \\
\text { members - the } \\
\text { experience of limits } \\
\text { goes hand in hand with } \\
\text { a stronger outward } \\
\text { orientation }\end{array}$ & $\begin{array}{l}\text { Stable partnership } \\
\text { Financially well-off } \\
\text { New resources through } \\
\text { leisure time and help } \\
\text { in the field of sports } \\
\text { and alternative } \\
\text { therapies }\end{array}$ & $\begin{array}{l}\text { GP, specialists, } \\
\text { individual talk } \\
\text { therapist, family talk } \\
\text { therapy, acupuncture, } \\
\text { Taiji, dancing, music, } \\
\text { archery, a gymnastics } \\
\text { group }\end{array}$ & $\begin{array}{l}\text { Comprehensibility: not } \\
\text { prepared for the 'female' } \\
\text { role, sister as an } \\
\text { unattainable role model } \\
\text { Manageability: takes a } \\
\text { step back from the role } \\
\text { of housewife and mother; } \\
\text { creates a parallel } \\
\text { network; uses } \\
\text { professional helpers } \\
\text { Meaningfulness: fragile } \\
\text { Participation: unclear; } \\
\text { has to look after } \\
\text { parents again whilst } \\
\text { starting a family } \\
\text { Emotional closeness: } \\
\text { yes, regarding the } \\
\text { partner, but problems } \\
\text { with the family of } \\
\text { origin }\end{array}$ \\
\hline $\begin{array}{l}\text { Mature } \\
\text { adulthood } \\
(\text { from 50) }\end{array}$ & $\begin{array}{l}\text { The eldest son } \\
\text { leaves home; the } \\
\text { parents need care } \\
\text { End-of-life care for } \\
\text { father (cancer) and } \\
\text { emotional support } \\
\text { for mother }\end{array}$ & $\begin{array}{l}\text { Transformation crisis } \\
\text { and reorientation }\end{array}$ & $\begin{array}{l}\text { Stable partnership, } \\
\text { financially well-off; } \\
\text { regular contact to the } \\
\text { sister } \\
\text { Turns hobby into a } \\
\text { profession (archery } \\
\text { trainer); mediation } \\
\text { training; access to } \\
\text { various support } \\
\text { systems; further } \\
\text { training in artistic } \\
\text { design, mediator } \\
\text { training }\end{array}$ & $\begin{array}{l}\text { GP: review dialogue; } \\
\text { specialist; alternative } \\
\text { therapy; can access } \\
\text { various support } \\
\text { systems (hospice } \\
\text { association, group for } \\
\text { dementia patients and } \\
\text { relatives, palliative care } \\
\text { doctors, hospice, Taiji, } \\
\text { painting) }\end{array}$ & $\begin{array}{l}\text { Comprehensibility: high, } \\
\text { but she can hardly escape } \\
\text { the operating rules } \\
\text { Manageability: manages } \\
\text { the terminal care } \\
\text { successfully, organizes } \\
\text { help (professional } \\
\text { helpers, sister, friends, } \\
\text { etc.). Body as mediator } \\
\text { Meaningfulness: rather } \\
\text { high } \\
\text { Participation: She } \\
\text { increasingly learns to } \\
\text { organize her own } \\
\text { space } \\
\text { Emotional closeness: } \\
\text { to husband (anchor); } \\
\text { also to sons }\end{array}$ \\
\hline
\end{tabular}

- As a child, Pamela experiences herself as particularly crucial in terms of the support of the mother and receives recognition for her seemingly remarkable independence. She develops the necessary knowledge of rules and handling skills for this, which go far beyond what can be expected at her age. Since the mother's fears are taboo as a central theme, there is a systematic limit to comprehensibility that lies like a veil of uncertainty over everyday life. Accordingly, the experienced recognition is not based on actual participation (see Antonovsky, 1987, p. 92), but on the successful completion of a role. Reduced attention to selfcare accompanies the development of care competencies.

- In young adulthood, some of these duties are transferred to the younger sister. Pamela 'pulls herself out' and seeks 
recognition through successes in studies and work. Here she reaches the limits of her social skills and experiences rejections that centrally touch the sense of meaningfulness. In this crisis, she receives considerable support from her future husband (emotional bonds), but after her sister's departure, she once again becomes the primary contact person for her mother.

- With birth and motherhood, Pamela Smith gives up the possibility of a professional career. She now opens up new social contacts and areas of realization outside the family through sport and health education.

- In the sixth decade of her life, she can fall back on this extended network. She can assess the situation (comprehensibility) and organize help (manageability). Therefore, to others such as her doctor at the beginning of review dialogues, her resources appear strong. However, she has difficulties in accepting the help and follows a traditional family pattern ('caring women') (meaningfulness). One could, therefore, assume that her sense of meaningfulness temporarily decreases with increasing awareness of her overall situation.

In the course of her life, Pamela Smith succeeds in differentiating her strategy of 'pulling herself out' in a socially acceptable way and in strengthening her sense of meaningfulness: In her artistic activities, she was able to express her specific style. Her mentor acknowledged that Pamela had her own world and was an artist. Pamela felt this as a knighthood since she had not studied art. Pamela Smith proudly sums up: 'I have quite a few facets' (Biographical interview).

\section{Discussion}

Our considerations on the sixth decade of life are based on the situation in modern industrialized countries, where with sometimes remarkable differences depending on social situation and cultural conditions - the average life expectancy is now over 80 years. Middle age is, therefore, less characterized by intervals related to years of life than by upcoming developmental tasks and is altogether a phase of transition in which a balance is being taken, and new orientations are possible.

An individual case cannot exhaust the variety of possible developmental trajectories. Still, it can illustrate a pattern that has heuristic value and contribute to the further development of research and practice. In the following, we discuss the relationship between the conceptual considerations presented at the beginning and our case study.

\section{Double Birth: Constitution and Personalization}

Pamela Schmidt not only has back problems as a constant companion, but she also lives them and redesigns herself and her environment accordingly. An active sportswoman, for example, becomes a coach who acknowledges her limitations and passes on her knowledge.

\section{Special Features of the Sixth Decade of Life}

Like many others, Pamela Smith's condition is becoming increasingly chronic - from a persistent illness to findings which, on closer examination, have a history that would have made an 'epicritic case evaluation' (Brucks et al., 1998, 43) worthwhile even in her 20s and 30s. Supporting and caring for the ageing parents are typical tasks of this phase of life, but in Pamela Smith's case, they are an explosive, ongoing issue. Thus, the question becomes virulent again with the care of the dying father: What is worth living for? In this situation, Pamela Smith can use the offer of the review dialogues (SRR) for a new orientation, strengthen her resources (GRR) and make her life more coherent, strengthening SOC.

\section{Critical Life Events}

The burdens associated with cancer, terminal care and the death of the father are dramatic. However, they are not entirely unexpected for Pamela Smith so that she can cope with them, partly with external help (SRR). The same applies to her own slipped disc. Her vision problems, on the other hand, are new, unexpected and throw her off track. The fact that she can readjust her gaze, so to speak, is a remarkable achievement and indicates a change that now allows her to define goals more strongly herself $(\mathrm{GRR} \rightarrow \mathrm{SOC})$. The crisis becomes an opportunity.

\section{Identity, SOC and Life Cycle}

We interpret Pamela Smith's development as a (dis)continuous process of learning and competence development, in the course of which she has reoriented herself and yet remained recognizable. Although she repeatedly encounters limits, which are mainly due to the logic of interaction and the context of obligations in her family of origin, she is increasingly succeeding in opening up a new scope and becoming a person recognizable beyond the role-mediated action ('person- 
alization'). Interestingly, the discrepancy between performance and autonomy becomes noticeable, so that her salutogenic resources seem to be decreasing despite the apparent development of competencies. We term this flexibilization (analogous to Antonovsky's reflections on the rigid SOC, Antonovsky, 1987, 24f), which is also expressed in increased attentiveness towards her own body.

\section{Development of the SOC}

For Pamela Smith, the development of the SOC is closely linked to health crises and upheavals. Illness and recovery are to be understood as temporary changes of location on the health-ease-disease continuum (Antonovsky, 1987). Phases of illness, although associated with limitations, can enable further development in the long term, so we propose to view the dynamic health-illness process as a whole, as 'the adaptation of the whole person to his entire past, to his present and to the visible forms of his future' (Sartre, 1981, p. 168).

Salutogenesis is both a biological and a social process (Sturmberg et al., 2019). Every human being is endowed with the capacity for self-regulation and yet, as a social being, cannot survive alone. The significant others enable, promote and limit the process of maturation, and thus salutogenesis takes place from the beginning as a bodily as well as a social process. If the abilities to cope with a situation are not sufficient (SRD) - for example, in case of chronic illness - professional support (SRR) may be necessary, ideally with a salutogenic orientation (Mittelmark et al., 2017).

Caring for patients with chronic conditions implicitly evokes the definition of life goals and the conduct of a healthy lifestyle. Treatment, life goals and lifestyle need to be aligned (Johnston et al., 2007). However, patients are often unaware of these interlinkages, and the general practitioner needs to create awareness around these issues and thereby provide the opportunity to reinvent their life history. Health and illness then cease to be real antagonisms (Antonovsky, 1987); they are strongly connected (Weizsäcker, 1956; Antonovsky, 1979, 1987) and part of the life process.

The presented person-centred care requires a new format of a conversation, empathy and time management (Coulter et al., 2013; Walseth et al., 2011; Derksen et al., 2017; Henselmans et al., 2015). We propose to perform review dialogues to apply this person-centredness. This case study shows the practical realizations of such professional interaction. This interaction needs to be designed as a process in which both conversation partners need to reinvent their roles as doctor and patient.
Doing this, both can experience that other ways of thinking and acting can be transferred. Ideally, in the sense of empowerment, this experience leads to lasting changes in behaviour and attitude patterns in everyday life and thus becomes a salutogenic resource (strengthening SOC). The experience with review dialogues shows that storytelling itself contributes to the development of health (Nünning \& Nünning, 2019). Still, it also shows that repeated offers and opportunities for discussion and thus a certain continuity are needed. Primary care must be developed into a healthpromoting setting (see Chap. 38 for a discussion of this issue).

According to our analysis, although the tasks Pamela Smith is facing become particularly urgent in the sixth decade of her life, they have been pending for some time. A resource-oriented offer of conversation - let's call this development dialogue - would, therefore, have made sense at an earlier point in time, starting, so to say, at another point of the health-ease-disease continuum.

The case study illustrates the limitations of medical interventions in doctor-patient interaction. Despite Pamela Smith's awareness and considerable personal resources, the patient does not succeed in becoming independent, due to her strong inner commitment towards her father and the experience of overwhelming social pressures.

Both, the patient and the general practitioner, sustain the established relationship pattern, and it might be assumed that Mrs. Smith will in the future continue to present somatic complaints to her general practitioner to recharge emotionally (Helmich et al., 1991). In the future, physical discomfort may continue to be a cause and expression of concern for Mrs. Smith, but in the knowledge of the possible professional help (SRR), and the experience of being able to rely on her family doctor (GRR), the visit can take place with less distress. The thought of the possible help may be occasionally enough (SOC), and the visits to the doctor may become less frequent. To prevent medicalization and somatic fixation, both actors will repeatedly be required to reject this invitation for constant repetition of their communication pattern and develop beyond it.

The case study underlines that the development of the SOC is a lifelong process and that change can be achieved even in (chronic) situations that appear to be frozen. It shows that such (health) crises indicate the need for change and can also be the beginning of change. It becomes clear that existing resources can be used for coping with them, of which those seeking help are often not even aware. It is evident that new potentials can be developed - and that for successful outcome support by 'obstetricians' with a 'sense for coherence' (Meier Magistretti et al., 2019) may be necessary. Given the 
current social organization of life courses, it is to be expected that such assessments and redrafts will become more frequent in the sixth decade of life. Still, given the pluralization of life plans, they are also possible in other stages of life. It, therefore, seems sensible to us to determine the individual need for support against the background of upcoming development tasks and longterm structuring life goals. As the health behaviour of women and men diverges, there are gender-specific resources and risk profiles to be considered.

\section{References}

Antonovsky, A. (1979). Health, stress and coping. Jossey-Bass.

Antonovsky, A. (1987). Unravelling the mystery health - How people manage stress and stay healthy. Jossey-Bass.

Backes, G. M. (1998). Individualisierung und Pluralisierung der Lebensverhältnisse: Familie und Alter im Kontext der Modernisierung. Zeitschrift für Familienforschung, 2, 5-29.

Backes, G. M., \& Wolfinger, M. (2009). Frauen ab 50 - 'andere' Chancen und Risiken des Alter(n)s? In B. Blättel-Mink \& C. Kramer (Eds.), Doing Aging - Weibliche Perspektiven des Älterwerdens (pp. 93-104). Nomos.

Bahrs, O. (2011a). Fallverstehen in der hausärztlichen Langzeitversorgung. Familiendynamik, 36(2), 2-11.

Bahrs, O. (2011b). Der Bilanzierungsdialog - Eine Chance zur Förderung von Ressourcenorientierung in der Langzeitversorgung von Patienten mit chronischen Krankheiten. GGW, 11(4), 7-15.

Bahrs, O. (2012). Hermeneutisches Fallverständnis - Versuch einer Annäherung. Z Allg Med, 88, 355-361. https://doi.org/10.3238/ zfa.2012.0355-0361

Bahrs, O., Heim, S., Löwenstein, F., \& Henze, K. H. (2017). Review dialogues as an opportunity to develop life course specific health goals. International Journal of Person Centered Medicine, 7, 98-106.

Bahrs, O., \& Henze, K. H. (2019). From shame to pride - Initiation of processes of De-stigmatisation in review dialogues. In C. Mayer \& E. Vanderheiden (Eds.), Transforming shame in culture and context: Practical applications and exercises for growth (pp. 363-378). Springer.

Bahrs, O., Henze, K. H., Löwenstein, F., Abholz, H. H., Ilse, K., Wilm, S., Bureick, G., \& Heim, S. (2015). Review dialogues as an opportunity to develop a person-related overall diagnosis. International Journal of Person Centered Medicine, 5, 112-119.

Bahrs, O., \& Matthiessen, P. F. (Eds.). (2007). Gesundheitsfördernde Praxen - Die Chancen einer salutogenetischen Orientierung in der hausärztlichen Praxis. Hans Huber.

Balint, E., \& Norell, J. S. (1975). Fünf Minuten pro Patient. Eine Studie über die Interaktionen in der ärztlichen Allgemeinpraxis. Suhrkamp.

Balint, M. (1957). The doctor, the patient and his illness. Tavistock.

Balint, M. (1975). Das Wiederholungsrezept: Behandlung oder Diagnose? Klett.

Bauman, Z. (2001). The individualized society. Polity Press.

Beutel, M. E., Brähler, E., \& Tibubos, A. N. (2019). Gender und psychische Gesundheit. Bedeutung für die psychotherapeutische Praxis. In I. Moeslein-Teising, R. Schäfer, \& R. Martin (Eds.), Geschlechter-Spannungen (pp. 54-65). Psychosozial Verlag.

Bohleber, W. (1997). Zur Bedeutung der neueren Säuglingsforschung für die psychoanalytische Theorie der Identität. In H. Keupp \&
R. Höfer (Eds.), Identitätsarbeit heute. Klassische und aktuelle Perspektiven der Identitätsforschung (pp. 93-119). Suhrkamp.

Braun-Lewensohn O, Idan O, Lindström B, Margalit M (2017) Salutogenesis: Sense of coherence in adolescence. In: Mittelmark MB, Sagy, S, Eriksson S, Bauer GF, Pelikan JM, Lindström B, Espnes GA (eds.) The handbook of Salutogenesis, Springer International Publishing, p 123-136.

Brucks, U., Wahl, W. B., \& Schüffel, W. (1998). Die Bedingungen für Veränderungen erkennen: Salutogenese in der Praxis. In W. Schüffel, U. Brucks, R. Johnen, V. Köllner, F. Lamprecht, \& U. Schnyder (Eds.), Handbuch der Salutogenese (pp. 37-53). Konzept und Praxis. Ullstein Medical.

Buddeberg, C. (Ed.). (2003). Psychosocial medicine. Springer.

Corbin, J. M., \& Strauss, A. L. (1988). Unending work and care: Managing chronic illness at home. Jossey-Bass.

Corbin, J. M., \& Strauss, A. L. (2004). Weiterleben lernen. Verlauf und Bewältigung chronischer Krankheit (2nd ed.). Hans Huber.

Coulter A, Roberts S, Dixon A. (2013). Delivering better services for people with long-term conditions: Building the house of care. The kings fund. http://www.kingsfund.org.uk/publications/deliveringbetter-services-people-long-term-conditions. Accessed 24 Apr 2017.

Derksen, F., Olde Hartman, T. C., Av, D., Plouvier, A., Bensing, J., \& Lagro-Janssen, A. (2017). Consequences of the presence and absence of empathy during consultations in primary care: A focus group study with patients. Patient Education and Counseling, 100, 987-993.

Eikelpasch, R., \& Rademacher, C. (2004). Identität. transcript. Verlag. Elwyn, G., Frosch, D., Thomson, R., et al. (2012). Shared decision making: A model for clinical practice. Journal of General Internal Medicine, 27, 1361-1367. https://doi.org/10.1007/ s11606-012-2077-6

Erikson, E. H. (1980). Identity and the life cycle. Norton.

Faltermaier, T. (2004). Männliche Identität und Gesundheit. Warum Gesundheit von Männern? In T. Altgeld (Ed.), Männergesundheit. Neue Herausforderungen für Gesundheitsförderung und Prävention (pp. 11-33). Weinheim.

Faltermaier, T. (2006). Die Salutogenese als Forschungsprogramm und Praxisperspektive. Anmerkungen zu Stand, Problemen und Entwicklungschancen. In H. Wydler, P. Kolip, \& T. Abel (Eds.), Salutogenese und Kohärenzgefühl. Grundlagen, Empirie und Praxis eines gesundheitswissenschaftlichen Konzepts (3rd ed., pp. 185196). Juventa.

Faltermaier, T. (2009). Gesundheit: Körperliche, psychische und soziale Dimensionen. In J. Bengel \& M. Jerusalem (Eds.), Handbuch der Gesundheitspsychologie und Medizinischen Psychologie (pp. 46-57). Hogrefe.

Geyer, J., \& Schulz, E. (2014). Who cares? Die Bedeutung der informellen Pflege durch Erwerbstätige in Deutschland. DIW Wochenbericht, 14, 294-303.

Gilleard, C., \& Higgs, P. (2019). The individualization of ageing. In P. Naskali, J. Harbison, \& S. Begum (Eds.), New challenges to ageing in the rural north. International perspectives on aging, vol 22 (pp. 241-251). Springer. https://doi. org/10.1007/978-3-030-20603-1_15

Goffman, E. (1975). Stigma. Über Techniken der Bewältigung beschädigter Identität. Suhrkamp.

Griebel, W., \& Niesel, R. (2011). Übergänge verstehen und begleiten. Transitionen in der Bildungslaufbahn von Kindern. Cornelsen.

Gugutzer, R. (2002). Leib, Körper und Identität. Eine phänomenologisch-soziologische Untersuchung zur personalen Identität. Westdeutscher Verlag.

Gugutzer, R. (2004). Soziologie des Körpers. transcript-Verlag. 
Hegemann, T., Asen, E., \& Tomson, P. (2000). Familienmedizin für die Praxis. Schattauer.

Helmich, P., Hesse, E., Köhle, K., Mattern, H. J., Pauli, P., Uexküll, T., \& Wesiack, W. (1991). Psychosoziale Kompetenz in der ärztlichen Primärversorgung. Springer.

Henselmans, I., Heijmans, M., Rademakers, J., \& Sv, D. (2015). Participation of chronic patients in medical consultations: patients' perceived efficacy, barriers and interest in support. Health Expectations, 18, 2375-2388.

Höfer, R. (2006). Kohärenzgefühl und Identitätsentwicklung. Überlegungen zur Verknüpfung salutogenetischer und identitätstheoretischer Konzepte. In H. Wydler, P. Kolip, \& T. Abel (Eds.), Salutogenese und Kohärenzgefühl. Grundlagen, Empirie und Praxis eines gesundheitswissenschaftlichen Konzepts (3rd ed., pp. 57-69). Juventa.

Honermann, H., Müssen, P., Brinkmann, A., \& Schiepek, G. (1999). Ratinginventar lösungsorientierter Interventionen: Ein bildgebendes Verfahren zur Darstellung ressourcen- und lösungsorientierten Therapeutenverhaltens. Vandenhoeck und Ruprecht.

Höpflinger F, Perrig-Chiello P. (n.d.) Mittleres Erwachsenenalter im gesellschaftlichen Wandel. Homepage Höpflinger, www.hoepflinger.com/fhtop/fhmidage1.html

Johnston, O., Kumar, S., Kendall, K., Peveler, R., Gabbay, J., \& Kendrick, T. (2007). Qualitative study of depression management in primary care: GP and patient goals, and the value of listening. The British Journal of General Practice, 57, 872-879.

Keupp, H. (1997). Diskursarena Identität: Lernprozesse in der Identitätsforschung. In H. Keupp \& R. Höfer (Eds.), Identitätsarbeit heute. Klassische und aktuelle Perspektiven der Identitätsforschung (pp. 11-39). Suhrkamp.

Keupp, H., Ahbe, T., Gmür, W., Höfer, R., Mitzscherlich, B., Kraus, W., \& Straus, F. (2006). Identitätskonstruktionen. Das Patchwork der Identitäten in der Spätmoderne (3rd ed.). Reinbek bei Hamburg.

Krappmann, U. (1975). Soziologische Dimensionen der Identität (4th ed.). Klett-Cotta.

Krappmann, U. (1997). Die Identitätsproblematik nach Erikson aus einer interaktionistischen Sicht. In H. Keupp \& R. Höfer (Eds.), Identitätsarbeit heute; Klassische und aktuelle Perspektiven der Identitätsforschung (pp. 66-92). Suhrkamp.

Lademann, J., \& Kolip, P. (2005). In B. Deitermann, J. Bucksch, \& M. Schwarze (Eds.), Gesundheit von Frauen und Männern im mittleren Lebensalter. Robert-Koch-Institut.

Leder, D. (1990). Clinical interpretation: The hermeneutics of medicine. Theoretical Medicine, 11, 9-24.

Lindström B, Eriksson M. (2010). The Hitchhiker's guide to Salutogenesis. Salutogenetic pathways to health promotion. Folkhälsan Research Centre, Health Promotion Research (eds.), Research Report, 2.

Maier-Gutheil, C. (2015). Lern- und Bildungsprozesse im Lebenslauf - Befunde empirischer Forschung und Perspektiven der Theorieentwicklung. Zeitschrift für Weiterbildungsforschung, Report 38:7-22. https://doi.org/10.1007/s40955-015-0008-y

Marotzki, W. (1990). Entwurf einer strukturalen Bildungstheorie: biographietheoretische Auslegung von Bildungsprozessen in hochkomplexen Gesellschaften. Weinheim.

Matthiessen, P. F. (2010). Paradigmenpluralität, Salutogenese und ärztliche Praxis. Der Mensch - Zeitschrift für Salutogenese und anthropologische Medizin, 41, 6-21.

Meier Magistretti, C., Topalidou, A., \& Meinecke, F. (2019). Sense FOR Coherence - der Sinn FÜR Kohärenz: Annäherungen an ein mögliches Konzept. In C. Meier Magistretti, B. Lindström, \& M. Eriksson (Eds.), Salutogenese kennen und verstehen (pp. 119135). Hogrefe
Mittelmark, M. B., Bull, T., Daniel, M., \& Urke, H. (2017). Specific resistance resources in the Salutogenic model of health. In M. B. Mittelmark, S. Sagy, S. Eriksson, G. F. Bauer, J. M. Pelikan, B. Lindström, \& G. A. Espnes (Eds.), The handbook of Salutogenesis (pp. 71-76). Springer International Publishing.

Nünning, V., \& Nünning, A. (2019). How to stay healthy and Foster Well-being with narratives, or: Where narratology and Salutogenesis could meet. In J. Alber \& G. Olson (Eds.), How to do things with narrative - Cognitive and diachronic perspectives (pp. 157-186). Walter de Gruyter.

Oevermann, U. (2000). Die Methode der Fallrekonstruktion in der Grundlagenforschung sowie der klinischen und pädagogischen Praxis In: Kraimer, K (ed) Die Fallrekonstruktion - Sinnverstehen in der sozialwissenschaftlichen Forschung (pp. 58-156). Suhrkamp.

Payer, L. (1993). Andere Länder, andere Leiden: Ärzte und Patienten in England, Frankreich, den USA und hierzulande. Campus.

Perrig-Chiello, P., \& Höpflinger, F. (2001). Zwischen den Generationen. Frauen und Männer im mittleren Lebensalter. Seismo Verlag.

Perrig-Chiello, P., Höpflinger, F., \& Suter, C. (2008). Generationen Strukturen und Beziehungen. Generationenbericht Schweiz.

Perrig-Chiello, P., \& Hutchison, S. (2010). Family caregivers of elderly persons. A differential perspective on stressors, Ressources and Well-Being. The Journal of Gerontopsychology and Geriatric Psychiatry, 23(4), 195-206.

Perrig-Chiello, P., \& Perren, S. (2005). Biographical transitions from a midlife perspective. Journal of Adult Development, 12(4), 169-181. https://doi.org/10.1007/s10804-005-7085-x

Robert Koch Institut (Ed.). (2014). Gesundheitliche Lage der Männer in Deutschland. Beiträge zur Gesundheitsberichterstattung des Bundes.

Rosenthal, G. (1995). Erlebte und erzählte Lebensgeschichte: Gestalt und Struktur biographischer Selbstbeschreibungen. Campus.

Sartre, J.-P. (1964). Marxismus und Existentialismus - Versuch einer Methodik. Rowohlt.

Sartre, J-P. (1977-1979). Der Idiot der Familie. Rowohlt, Reinbek bei Hamburg, (Vol 1-5).

Sartre, J.-P. (1981). The family idiot: Gustave Flaubert 1821-1857. Vol. 1 (trans. Cosman, C.). University of Chicago Press.

Sturmberg, J. P., Picard, M., Aron, D. C., Bennett, J. M., Bircher, J., de Haven, M. J., Gijzel, S. M. W., Heng, H. H., Marcum, J. A., Martin, C. M., Miles, A., Peterson, C. L., Rohleder, N., Walker, C., Olde Rikkert, M. G. M., \& Melis, R. J. F. (2019). Health and disease - emergent states resulting from adaptive social and biological network interactions. Frontiers in Medicine, 6, 59. https://doi. org/10.3389/fmed.2019.00059

Uexküll, T. (Ed.). (2004). Psychosomatische Medizin (4th ed.). Urban und Schwarzenberg.

Ventegodt, S., Andersen, N. J., \& Merrick, J. (2003). The life Mission theory II. The structure of the life purpose and the Ego. The Scientific World Journal, 3, 1277-1285. https://doi.org/10.1100/ tsw.2003.114

Vogel, C., Wettstein, M., \& Tesch-Römer, C. (2019). Frauen und Männer in der zweiten Lebenshälfte - Älterwerden im sozialen Wandel. Bundesministerium für Familie, Senioren. In Frauen und Jugend (Ed.), Frauen und Männer in der zweiten Lebenshälfte Älterwerden im sozialen Wandel. Zentrale Befunde des Deutschen Alterssurveys (DEAS) 1996 bis 2017. Bundesministerium für Familie, Senioren, Frauen und Jugend (BMFSFJ).

Vossler, A. (2001). Der Familien-Kohärenzsinn als kollektives Konzept: Das Ganze ist mehr als die Summe seiner Teile. Zeitschrift für Gesundheitspsychologie, 9, 112-122. 
Walseth, L. T., Abildsnes, E., \& Schei, E. (2011). Patients' experiences with lifestyle counselling in general practice: A qualitative study. Scandinavian Journal of Primary Health Care, 29, 99-103.

Weizsäcker, V. (1930). Soziale Krankheit und soziale Gesundung. Springer.

Weizsäcker, V. (1956). Pathosophie. Vandenhoeck und Ruprecht.
Wetzstein, M., Rommel, A., \& Lange, C. (2015). Pflegende Angehörige - Deutschlands größter Pflegedienst. In Robert KochInstitut Berlin (Ed.). GBE kompakt. https://doi.org/10.17886/ RKI-GBE-2016-018

Open Access This chapter is licensed under the terms of the Creative Commons Attribution 4.0 International License (http://creativecommons. org/licenses/by/4.0/), which permits use, sharing, adaptation, distribution and reproduction in any medium or format, as long as you give appropriate credit to the original author(s) and the source, provide a link to the Creative Commons license and indicate if changes were made.

The images or other third party material in this chapter are included in the chapter's Creative Commons license, unless indicated otherwise in a credit line to the material. If material is not included in the chapter's Creative Commons license and your intended use is not permitted by statutory regulation or exceeds the permitted use, you will need to obtain permission directly from the copyright holder. 